\title{
Ignatius of Antioch and the Apostle Paul
}

\author{
Andrew Daunton-Fear
}

St. Andrew's Theological Seminary, Manila

undauntedstill@gmail.com

\section{Summary}

This paper looks at the establishment of the church in the city of Antioch in Syria, and the part played by the apostle Paul in its early history. It then examines the indebtedness of Ignatius to the apostle as seen in his letters written nearly half a century after Paul's death. Finally it suggests why the bishop outstrips his model in his zeal for martyrdom.

\section{Keywords}

church - Antioch - Apostle Paul in Antioch history

The city of Antioch was founded in 300 BCE and, following the conquests of Pompey, in 64 BCE was made capital of the Roman province of Syria. In the first century CE it was the third city of the Roman Empire after Rome and Alexandria with a mixed population of Syrians, Greeks, Jews and Romans. According to Luke, after the death of Stephen the Christian Gospel was first preached there to Gentiles as well as Jews and with great success (Act 11:19-21). Barnabas was sent from the church in Jerusalem to check on what was happening and, convinced it was indeed the work of God, went to Tarsus and fetched the converted rabbi Saul to assist in establishing the church there (Act 11:22-26). The remarkable work continued and soon Barnabas and Saul were sent out by that church to engage in wider evangelistic activity. So began the great missionary journeys of Saul (Roman name Paul), the "Apostle to the Gentiles." According to Acts Antioch remained the base for his work (14.26, 15.35-36, 18.22-23).

In Gal 2:1-10 Paul tells of his visit with Barnabas to Jerusalem to meet the "pillars" of the Jerusalem church (James the Lord's brother, Peter and John) who then acknowledged the legitimacy of his Gospel and mission to the 
Gentiles; but Paul goes on to relate how subsequently he had to challenge Peter at Antioch for breaking off table fellowship with the Gentile Christians after the arrival of "certain people from James." In the dispute Paul articulated "justification by faith" (Gal 2:11-21). Doubting the historical reliability of Acts, David C. Sim, in his study The Gospel of Matthew and Christian Judaism, suggests that Paul lost the argument and left Antioch, never to return; the church there then adhered to the Torah under the leadership of Peter who was subservient to James. ${ }^{1}$ However, with the fall of Jerusalem to the Romans in $70 \mathrm{CE}$ and the scattering of the Jerusalem church, Sim believes, Pauline Hellenistic Christianity revived in Antioch. ${ }^{2}$ Towards the end of the century the Gospel of Matthew was written among the Judaeo-Christians in that city, ${ }^{3}$ but these were out of fellowship with the Hellenists over whom Ignatius had been appointed leader. It has been further surmised that these Judaeo-Christians denounced Ignatius to the Roman authorities, as a result of which he was arrested and sent for execution in Rome. ${ }^{4}$ This is an interesting reconstruction, but it is by no means assured. We do not know how the dispute between Paul and Peter in Antioch was settled. It is possible that Peter conceded Paul was right (cf. 1 Pet 3:8-9), that Pauline Gentile Christianity prevailed there as generally elsewhere and, in due time, Ignatius was chosen as leader of the whole church. The messages at the end of Ignatius' letters do not speak of division within that church but rather suggest that the whole church had experienced persecution initiated by pagans. ${ }^{5}$ Pliny, in his letter to Trajan, reveals just such a persecution at that time in Bithynia. ${ }^{6}$

1 D. Sim, The Gospel of Matthew and Christian Judaism: The History and Social Setting of the Matthean Community, Edinburgh, 1998, pp. 100-106.

2 Ibid., 271.

3 Ibid., 109, 283.

4 S. Tugwell, The Apostolic Fathers, London, 1989, p. 123; C. Trevett, A Study of Ignatius of Antioch in Syria and Asia, Lewiston, 1992, pp. 180-183.

5 Rom. 9 tells of the church as having Christ as head because Ignatius has been removed from leadership, Rom. 10 refers to others sent ahead of Ignatius to Rome "for the glory of God" martyrdom? Philad. 11 speaks of Rheus Agathopou, "one of the elect, who has followed after me from Syria, and abjured this earthly life" - clearly another martyr. Smyrn. 11 speaks of "the restoration of peace ... their recovery of their proper numbers, and ... their re-establishment as a corporate body again" (tr. Staniforth; cf. Philad. 10, Poly. 7).

6 Epistle 10.96. The policy Trajan then laid down would have done little to prevent such persecutions, except that anonymous accusations against Christians were disallowed (Pliny, Epistle 10.97). 
According to Eusebius, Ignatius was the third bishop of Antioch. ${ }^{7} \mathrm{He}$ is known from seven letters attributed to him, ${ }^{8}$ written c. $110 \mathrm{CE}$ in an exuberant style now recognized as "Asianic" rhetoric. Clearly he was a great admirer of Paul for in his letter to the Ephesians he speaks of him as "Paul, who was sanctified, who also was approved [or 'martyred' - memarturēmenou], who is deservedly blessed - may I be found in his footsteps when I reach God!" (12.2, tr. Holmes). Further, in his letter to the Romans Ignatius declares he is not issuing orders "as though I were a Peter or a Paul. They were Apostles and I am a condemned criminal" ( 4.3 tr. Staniforth). Here it is evident he not only accepts the apostleship of Paul but places him alongside Peter. The very fact that Ignatius wrote letters to churches may have been in conscious imitation of Paul, though it is clear he made no pretensions to being an apostle himself.

Though Ignatius' letters were written hurriedly while he was chained to ten "leopards" (soldiers) on his journey from Antioch to Rome (Rom.5.1), there are clear echoes of Pauline letters in his writings, none more obvious than when in Ephes. 18.1 he speaks of "The Cross which is a stumbling-block to those that do not believe, but to us salvation and life eternal. Where is the wise man (pou sophos)? Where the disputer (pou suzêtētēs)? Where is the boasting of those who are styled prudent?" (ANF). Compare this with 1 Cor 1:18,20: "The word of the cross is folly to those who are perishing, but to us who are being saved it is the power of God ... Where is the wise man (pou sophos)? Where is the scribe? Where is the debater (pou suzètètès) of this age?" (RSv). Further, in Ephes. 8.2 he contrasts "carnal" and "spiritual" people, as Paul does in 1 Cor 3:1. Ignatius' reference to Jesus Christ as the "New Man" in Ephes. 20 recalls 1 Cor 15:45-47 and Rom 5:12-14 and, in the same passage, he refers to "Jesus Christ, who is the seed of David according to the flesh and is the Son of Man and Son of God" which resembles Paul's similar description of Jesus in Rom 1:3-4. In Poly. 5 he tells the young bishop Polycarp to charge Christian men "to love their wives as the Lord loves the Church" - the simile expounded by Paul at length in Eph 5:25-33. In one striking passage Ignatius appears to allude to Paul's doctrine of justification by faith:

I heard some say, 'If I do not find (it) in the archives, I do not believe it in the gospel'... But for me, the archives are Jesus Christ, the inviolable archives are his cross and death and his resurrection and faith through him, in which, through your prayers, I want to be justified (dikaiōthēnai). (Philad. 8.2, tr. Schoedel)

7 Historia Ecclesiastica 3.22,36.

8 Accepting the shorter recension of these which has long been generally accepted as genuine. 
Ignatius has been telling the church at Philadelphia to shun Judaism and, in this passage he appears to be quoting the very words of Judaeo-Christians (in Antioch?). The "archives" (archeiois) surely refer to the Old Testament. ${ }^{9}$ It is not the statements there, he says, that are of fundamental importance but the actual historical events of the death and resurrection of Jesus Christ, and putting one's faith in him. Lindemann believes that in this passage Ignatius is drawing on Paul's cardinal doctrine..$^{10}$ Dassmann comments that Ignatius' silence about it elsewhere is not due to his rejection of it but to his acceptance of it and no longer needing to emphasise it. ${ }^{11}$ Consonant with justification are Ignatius' reference elsewhere to "Jesus Christ who died for us, that by believing in his death you may escape dying" (Trall. 2.1, cf. Smyrn. 1.1,2), and his warning, "Let no one be deceived: even heavenly powers and the glory of angels [or better 'and the glorious angels'] and the rulers, both visible and invisible, if they do not believe in the blood of Christ, are also subject to judgment" (Smyrn. $6.1)$.

But if Ignatius would appear in sympathy with Paul's statement in Phil 3:9 that he has no righteousness of his own "based on law, but that which is through faith in Christ,"12 time and again he echoes rather Paul's sentiments in Phil 3:10-12 of wanting to share in the sufferings and death of Christ that somehow he might attain the resurrection from the dead. Indeed Ignatius says he yearns for martyrdom with the passion of a lover (Rom. 7), seeing it as his one assured way of attaining Christian discipleship and securing salvation. ${ }^{13}$ Nowhere does he state this more emphatically than in his letter to the Romans where he pleads with them not to try to avert his death in the arena:

Let me be food of wild beasts through whom it is possible to attain God; I am the wheat of God, and I am ground by the teeth of wild beasts that I may be

9 A Hellenistic-Jewish conception - W.R. Schoedel, Ignatius of Antioch: A Commentary on the letters of Ignatius of Antioch, Philadelphia, 1985, p. 17.

10 A. Lindemann, Paulus, Apostel und Lehrer der Kirche, Tübingen, 1999, S. 271.

11 E. Dassmann, Der Stachel im Fleisch: Paulus in der frühchristlichen Literature bis Irenäus, Münster, 1979, S. 145 .

Pace the "new perspective" on Paul which would translate here dia pisteōs Xristou "through the faithfulness of Christ." It has been aptly remarked that Paul lays no stress on the faithfulness of Christ in his extended exposition of justification in Romans - J.A. Fitzmyer, Romans: A New Translation with Introduction and Commentary, New York, 1993, p. 345. Paul's focus is rather on faith and its contrast with works.

Trall. 12.2, Rom. 4.1-3, 5.3, 6-7, Smyrn. 4.2, Poly. 7.1. 
found pure bread; instead, entice the wild beasts that they may become my tomb and leave behind no part of my body that when I fall asleep, I may burden no one. Then I shall truly be a disciple of Jesus Christ when the world will not even see my body. Pray Christ for me that by these means I may be found a sacrifice of God.

May I benefit from the wild beasts prepared for me, and I pray that they will be found prompt with me, whom I shall even entice to devour me promptly... now I begin to be a disciple. May nothing of things visible or invisible envy me, that I may attain Jesus Christ. Fire and cross, and packs of wild beasts, the wrenching of bones, the mangling of limbs, the grinding of my whole body, evil punishments of the devil - let these come upon me, only that I may attain Jesus Christ! (4.1-2, 5.2-3, tr. Schoedel)

Why does Ignatius, a bishop from Antioch in Syria, to whom churches along his route send respectful delegations, have the extraordinary idea that he must fight with beasts and die in the arena in Rome to attain true Christian discipleship? A notable feature of almost all Ignatius' letters is his denigration of himself as the "last" or "least" of all the members of the Syrian church, unworthy to be called a member. ${ }^{14}$ Here he clearly echoes Paul's self-deprecation, even to the extent of referring to his new birth as being like an abortion. ${ }^{15}$ It seems natural then to conclude that Ignatius, like Paul himself, had, before becoming a Christian, been an opponent of the church or was guilty of some other major misdemeanour. ${ }^{16}$ On account of this, when he had been elevated to leadership of the church in Antioch, some of his opponents may well have flung at him the assertion that he was "not worthy to be called a disciple of Christ." He then seized on this chance of martyrdom as a means of indisputably establishing his Christian discipleship.

\footnotetext{
14 Rom. 9.2, Ephes. 21.2, Trall. 13.1, Smyrn. 11.1, Magn. 14.

15 Ignatius, Rom. 9.2, cf. 1 Cor. 15.8.

16 Returning to the view of J.B. Lightfoot, pace Schoedel, Ignatius, p. 13.
} 